\title{
Resistance to Cucumber Green Mottle Mosaic Virus in Cucumis melo
}

\author{
Leticia Ruiz $^{1}\left(\mathbb{D}\right.$, Carmelo López $^{2}(\mathbb{D})$, Belén Picó ${ }^{2}$ and Dirk Janssen ${ }^{1, *(\mathbb{D})}$ \\ 1 IFAPA, Centro La Mojonera, 04745 La Mojonera, Spain; mleticia.ruiz@juntadeandalucia.es \\ 2 Institute for the Conservation and Breeding of Agricultural Biodiversity (COMAV), \\ Universitat Politècnica de València, Camino de Vera s/n, 46022 Valencia, Spain; clopez@upv.es (C.L.); \\ mpicosi@btc.upv.es (B.P.) \\ * Correspondence: dirk.janssen@juntadeandalucia.es
}

check for updates

Citation: Ruiz, L.; López, C.; Picó, B.; Janssen, D. Resistance to Cucumber Green Mottle Mosaic Virus in Cucumis melo. Plants 2021, 10, 1077. https://doi.org/10.3390/ plants10061077

Academic Editors: Kazusato Ohshima and Aviv Dombrovsky

Received: 8 April 2021

Accepted: 24 May 2021

Published: 27 May 2021

Publisher's Note: MDPI stays neutral with regard to jurisdictional claims in published maps and institutional affiliations.

Copyright: (c) 2021 by the authors. Licensee MDPI, Basel, Switzerland. This article is an open access article distributed under the terms and conditions of the Creative Commons Attribution (CC BY) license (https:// creativecommons.org/licenses/by/ $4.0 /)$.

\begin{abstract}
Cucumber green mottle mosaic virus (CGMMV) is a severe threat to melon production worldwide. At present, there are no cultivars available on the market which show an effective resistance or tolerance to CGMMV infection; only wild Cucumis species were reported as resistant. Germplasm accessions of Cucumis melo, as well as C. anguria, C. ficifolius, C. myriocarpus and C. metuliferus, were mechanically infected with isolates belonging to the European and Asian strain of CGMMV and screened for resistance by scoring symptom severity and comparing the accumulation of virus by qRT-PCR. The wild species C. anguria and C. ficifolius showed no symptoms and did not accumulate CGGMV following inoculation, while $C$. metuliferus was highly susceptible to the isolates of both strains of CGMMV. The virus accumulated also in C. myriocarpus and the European isolate produced symptoms, but the Asian isolate did not. Thirty C. melo accessions were susceptible to CGMMV. An isolate-dependent expression of symptoms was observed in 16 melon accessions: they showed mild and severe symptoms at 14 and 21 days after inoculation with the European and Asian isolate, respectively. Freeman's Cucumber showed few or no symptoms following inoculation with the isolate of either CGMMV strain. This particular accession also showed reduced virus accumulation, whereas most other tested germplasm accessions showed significantly higher viral loads and, therefore, may well be a candidate for breeding programs aiming to reduce the losses produced by CGMMV with resistant commercial melon cultivars.
\end{abstract}

Keywords: real-time RT-PCR; viral load; CGMMV; tobamovirus

\section{Introduction}

Diseases produced by viruses cause economic losses in commercial cucurbit production around the world [1]. Among these viruses, cucumber green mottle mosaic virus (CGMMV) represents a major risk to the production of melons, watermelons and cucumbers. CGMMV belongs to the genus Tobamovirus, family Virgaviridae [2], and causes systemic mottle and mosaic symptoms on the leaves of cucurbitaceous plants. In susceptible watermelon genotypes, the virus causes a pulp deterioration called blood flesh disease and the fruit loses its marketable value [3]. In cucumbers, the virus causes deformation and mosaic symptoms [4]. In melons, young leaves develop initial mottle and mosaic symptoms that often disappear from mature foliage. Their fruits develop different degrees of malformation, mottling and surface netting [5]. It is mechanically, pollen- and seed-transmitted [6].

CGMMV was first described infecting cucumbers in England in 1935 by Ainsworth [7]. Its incidence in other countries of the world has increased rapidly during the last decade, possibly through the international seed trade following cucurbit seed crop production in tropical or subtropical countries [6]. Moreover, seed-testing routines for CGMMV may be inadequate, which allows for the rapid and worldwide spread of the virus. Contaminated seeds provide a route for the movement of the virus between countries and its introduction 
into new areas, and several seed treatments currently used were found to be insufficient for eliminating the virus from contaminated seed lots. In addition, like other tobamoviruses, CGMMV can survive for a long time on plant debris from infected crops [8]. Therefore, control depends on early monitoring, awareness of the farmers and appropriate crop management, but even implementing these measures does not guarantee success [9].

Worldwide, CGMMV isolates are grouped in two major clusters based on biological differences and genome sequences: a first cluster constitutes the European strain and includes most isolates from France, the Netherlands and Uzbekistan. A second cluster is formed by isolates from Asian countries, such as Japan and South Korea. Spain is currently the first country where both these strains have been described co-infecting the same crops and in the same region [10]. Although isolates of both strains differ in their genome sequences, they do not differ in terms of the systemic symptoms expressed on leaves of infected cucumbers. However, they behave differently in Chenopodium amaranticolor, on which local lesions appear only when isolates of the Asian strain are inoculated [10].

Commercial tomato and pepper hybrids that carry virus-resistant genes successfully control tobamoviruses in solanaceous crops. Resistance is an important factor that determines concentrations of virus in several virus-cucurbits host plant pathosystems. This happens, for example, with cucurbit yellow stunting disorder virus and Watermelon mosaic virus in melon [11-13]. However, in the case of CGMMV, there is an urgent need for resistant melon cultivars that have restricted movement and replication of virus as well as reduced symptom development. Melon is an important crop, of which about 150 million tons of fruit are produced worldwide, including 66,000 tons in Spain during 2018 [14]. However, commercial melon varieties resistant to CGMMV are currently unavailable. Efforts have been made to produce transgenic resistance in melon [15]. The development of resistant varieties through conventional breeding could offer a good solution to this disease, which continues to escalate.

Rajamony et al., screened 187 accessions of C. melo and eight wild Cucumis species. Six wild species were found to be resistant (C. africanus, C. ficifolius, C. figarei, C. meeussii, C. myriocarpus and C. zeyheri) but only a few accessions of the Indian momordica and Kachri melon groups displayed a partially resistant response, with recessive and polygenic control [16-18]. Others confirmed the behavior as symptomless carriers of momordica accessions and the immune response of C. figarei and C. zeyheri [19]. Apart from these melon types, new resistance was reported in a Korean accession of the oriental makuwa group [20]. Resistance was partial and temperature-dependent, and controlled by two independent complementary recessive genes [21]. These previous studies used isolates from the Asian type of CGMMV. Thus, no full resistance to the virus has been reported yet in melon.

In the present paper we inoculated isolates belonging to the European and the Asian strain of CGMMV in a collection of 47 accessions of $C$. melo, selected to represent the variability of the species, and four wild Cucumis species: C. anguria, C. ficifolius, C. metuliferus and C. myriocarpus. We report on the evolution of symptom expression for both virus isolates in all accessions, and that of the viral loads on a representative number of accessions.

\section{Results}

\subsection{Symptom Expression}

Single inoculations in melon accessions with CGMMV isolates CGMMV-SP and CGSPCu16 that represent the European and the Asian strains, respectively, produced symptoms that were scored according to the scales from 0 to 3, as defined in the Materials and Methods (Figure 1). 

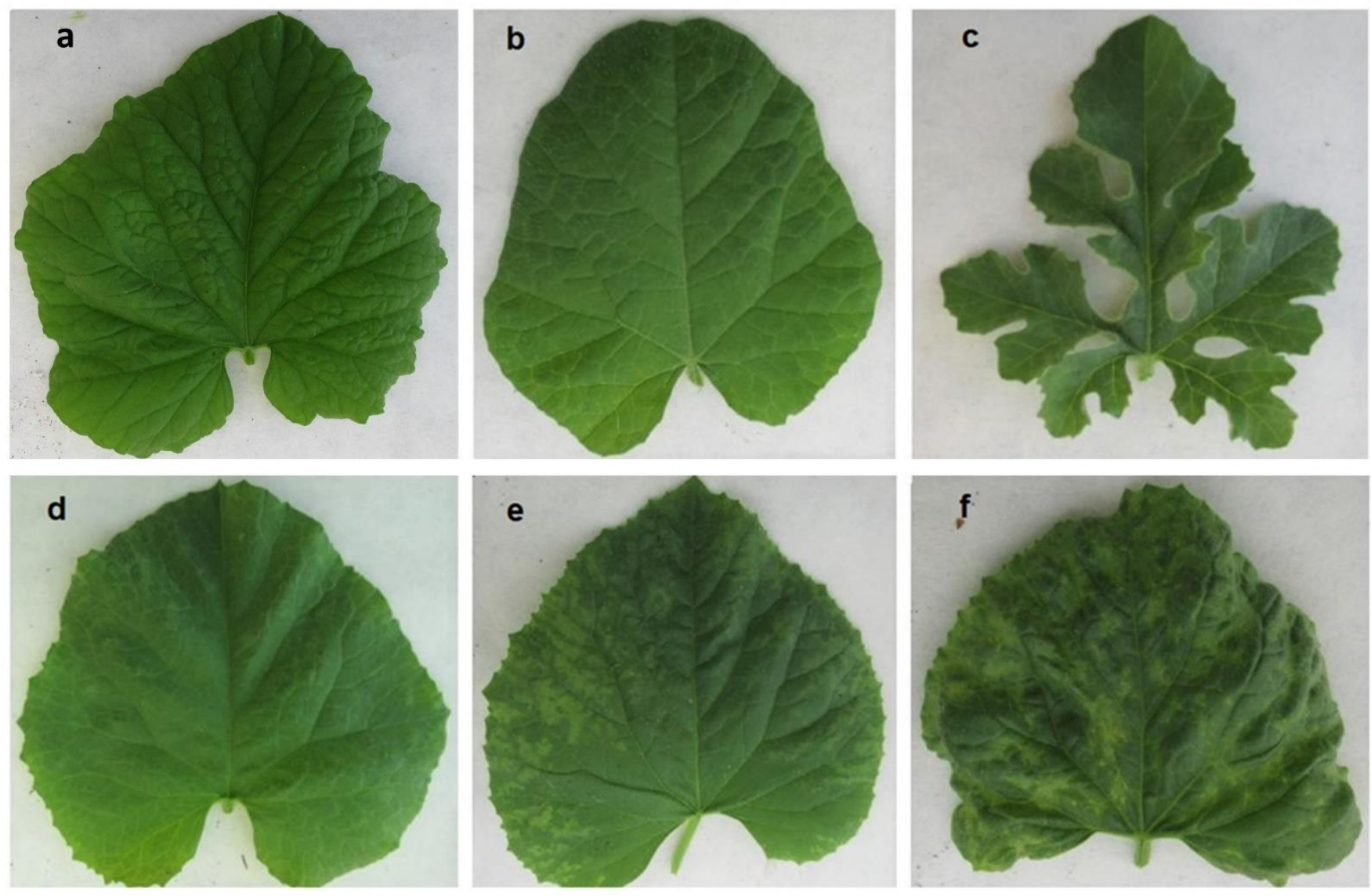

Figure 1. Range of symptoms of CGMMV in Cucumis at 15 days following inoculation with CGMMV-SP: (a) “0” in Freeman's Cucumber, (b) in C. ficifolius, (c) in C. myriocarpus, (d) "1" in PMR-45, (e) "2" in PI 125951 and (f) "3" in PI 314427, as representative $C$. melo accessions.

The time of appearance of these symptoms in individual plants was variable, but most of the replicate plants of each accession showed similar symptoms at $21 \mathrm{dpi}$ (Table S1). The plants were observed beyond that time, but no change in the symptoms was spotted. Severe symptoms (score 3) were found following inoculation with both isolates in $24 \mathrm{C}$. melo accessions which belonged to the Asian ameri and the Spanish ibericus types, such as Birjucekutskaja and Piñoncillo, but also to the Asian Dudaim types, Indian Kachri and momordica and African and Indian wild agrestis, as well as to oriental conomon melons.

Some melon accessions also showed severe symptoms against CG-SPCu16, but intermediate symptoms with CGMMV-SP (the Spanish ibericus Rochet accession BGV004884 and the makuwa accession PI 420176 from Japan) while two others showed intermediate symptoms with CG-SPCu16 and severe symptoms with the European isolate (the oriental chinensis accession PI 161375 and the flexuosus melon BGV004853). Two additional melon accessions were also susceptible, but the Indian momordica PI 381789 displayed intermediate symptoms with both virus isolates, while the Khira melon from India PI 271332 had a variable response to the virus isolate CG-SPCu16. A virus isolate-dependent expression of symptoms was observed in 16 melon accessions: they showed mild and severe symptoms at 14 and 21 dpi when infected with the European and Asian isolate, respectively (many ameri, chandalak or casaba types from Eastern Europe, Asia Minor, Central Asia and Northern Africa and the cantalupensis and reticulatus groups, such as the Turkish Kirkagac accession PI 169305, the Georgian Nanatri melon or the cantalupensis Dvash Ha Ogen). The only accession resistant to both isolates of the virus was the conomon Japanese accession Freeman's Cucumber. Regarding wild types, C. metuliferus expressed severe symptoms with the isolates of both CGMMV strains, and C. myriocarpus displayed intermediate symptoms following the inoculation with CGMMV-SP and none 
with CG-SPCu16. The inoculation with CGMMV produced no symptoms in C. anguria, and C. ficifolius (Table S1).

\subsection{CGMMV Viral Loads}

Plants inoculated with CGMMV had relative viral loads that ranged from undetected to values of $3.16 \mathrm{e}^{9}$ (BGV015753 at $14 \mathrm{dpi}$ SP) (Table S2).

Among the wild Cucumis species, C. anguria and C. ficifolius tested negative for CGMMV, whereas CGMMV concentrations in C. metuliferus and C. myriocarpus ranged between the orders of $\mathrm{e}^{5}$ to $\mathrm{e}^{7}$ with the CGMMV-SP, and $\mathrm{e}^{3}$ to $\mathrm{e}^{4}$ with CG-SPCu16. Melon accessions that showed severe symptoms with both virus isolates had similar viral loads at 14 and $21 \mathrm{dpi}$ (Figure 2). However, the European isolate accumulated less than the Asian isolate at $21 \mathrm{dpi}$ in accessions in which it produced milder symptoms when compared with the Asian isolate $(p<0.05)$ (Figure 3). Freeman's Cucumber also accumulated smaller amounts of virus (maximum viral load value $7.44 \mathrm{e}^{2}$ at $14 \mathrm{dpi}$ with CGMMV-SP), and CGMMV was not detected at $21 \mathrm{dpi}$ in plants inoculated with CG-SPCu16 (Table S2). The average viral loads correlated with the expression of symptoms (Figure 4).

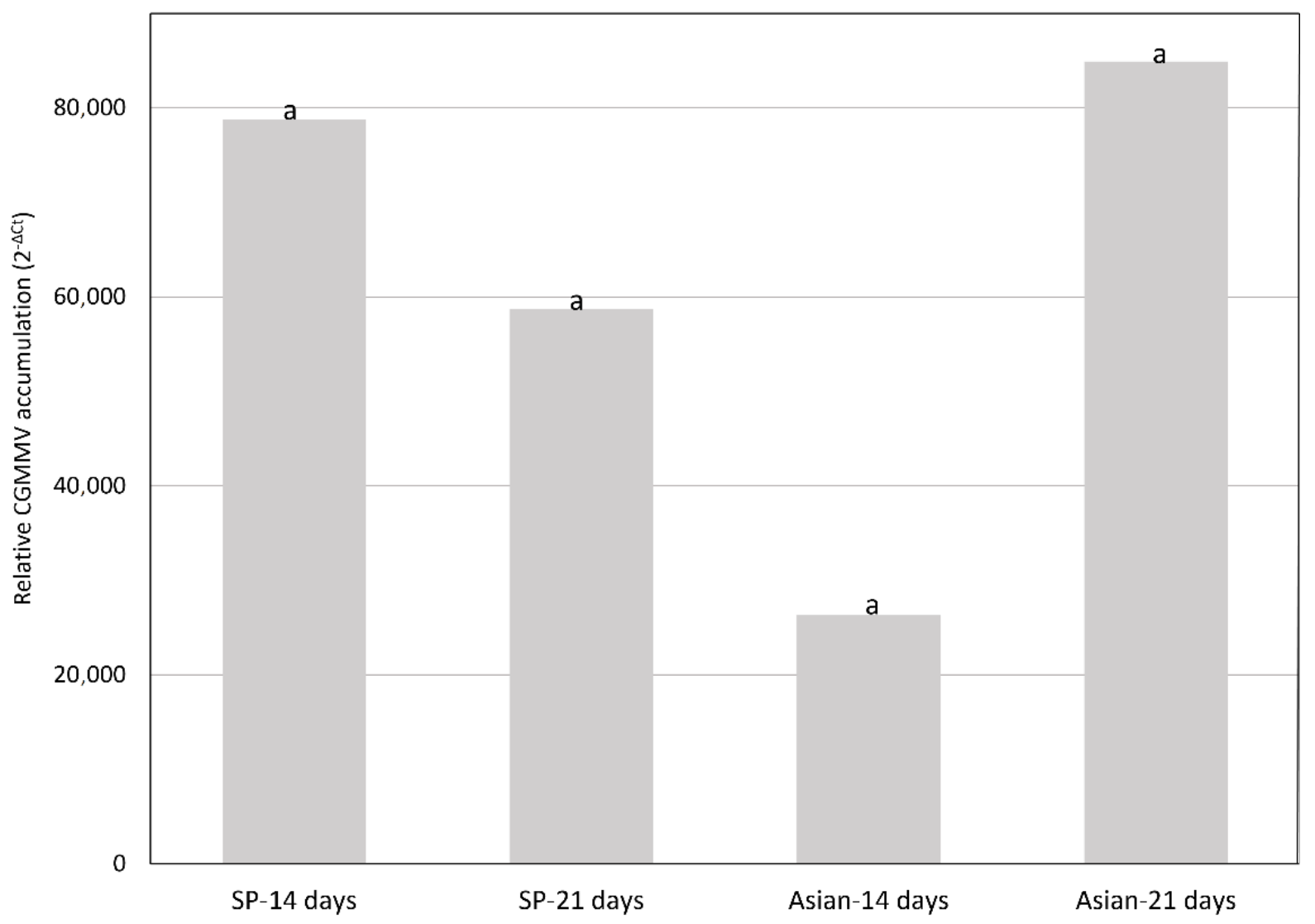

Figure 2. Mean of relative cucumber green mottle mosaic virus (CGMMV) accumulation (calculated as $2^{-\Delta \mathrm{Ct}}$ ) at 14 and 21 days following inoculation in plants susceptible to the European (CGMMV-SP) and Asian (CG-SPCu16) isolates $(n=30)$. Letters show no significant differences were found between the variables ( $\alpha=0.05$, Kruskal-Wallis test). 


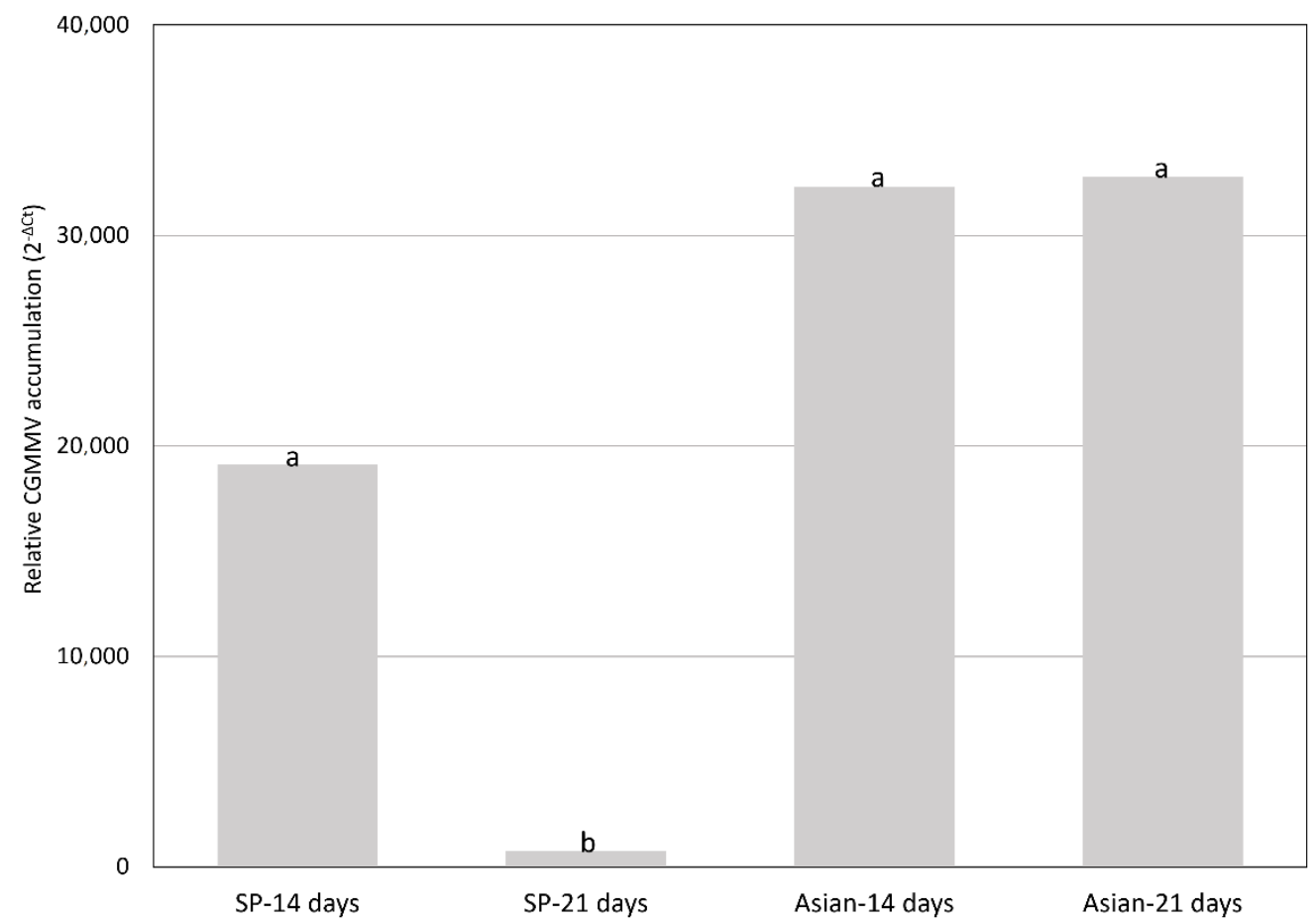

Figure 3. Mean of relative cucumber green mottle mosaic virus (CGMMV) RNA accumulation (calculated as $2^{-\Delta \mathrm{Ct}}$ ) at 14 and 21 days following inoculation in plants resistant to the European (CGMMV-SP) and susceptible to the Asian isolates (CG-SPCu16) $(n=16)$. Letters show significant differences found between the variables $(\alpha=0.05$, Kruskal-Wallis test).

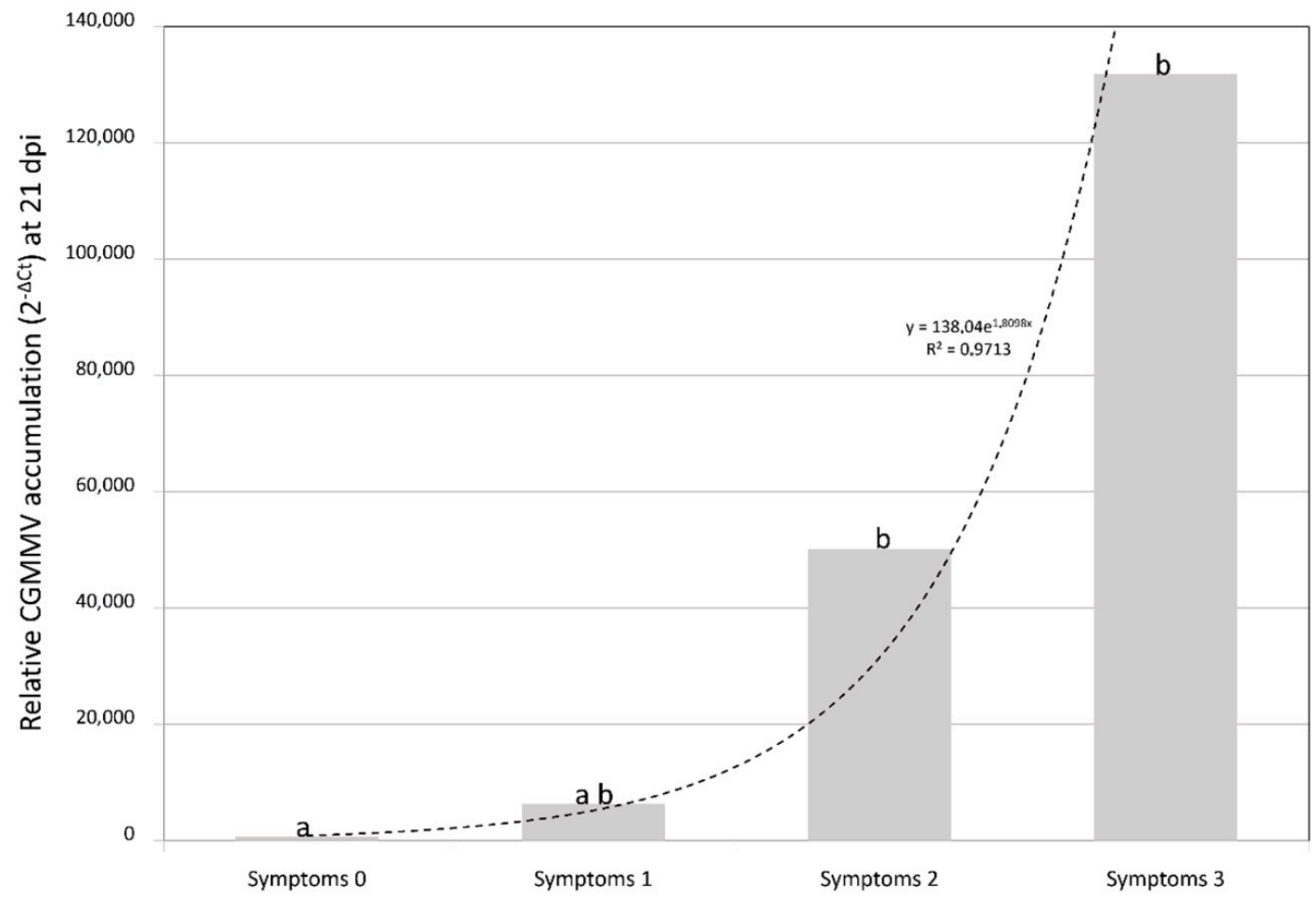

Figure 4. Mean of relative cucumber green mottle mosaic virus (CGMMV) accumulation (calculated as $2^{-\Delta C t}$ ) in plants within symptomatic classes $0(n=16), 1(n=2), 2(n=9)$ and $3(n=67)$. The dotted line represents the exponential relationship between both variables. Letters show significant difference found between the variables $(\alpha=0.05$, Kruskal-Wallis test). 


\section{Discussion}

We tested a collection of 47 melon accessions for resistance to CGMMV. The majority of genotypes were very susceptible after mechanical inoculation, as was made clear by the expression of typical CGMMV symptoms and the accumulation of virus in apical leaves. The high susceptibility observed along the whole range of diversity of this species confirmed that this virus represents a major threat to melon cultivation. The majority of the accessions tested were susceptible to the European (CGMMV-SP) and the Asian (CG-SPCu16) isolates of CGMMV, which is relevant to countries such as Spain, where both strains occur, sometimes even in the same greenhouse [10] Among these accessions were Spanish landraces, which may have been as expected, since they do not usually have resistances to viruses. Interestingly, within the Spanish accessions, two, Rochet (BGV004884) and Alficos (BGV004853), showed a milder response to the European and Asian isolates of CGMMV, respectively, which is relevant in view of the recovery of its cultivation in Spain [22].

Equally susceptible as most Spanish landraces were also most of the accessions of Asian origin that belong to many melon groups such as ameri, Dudaim, even certain wild types (wild agrestis accessions PI 164797, PI 185111 or PI 536476) and Kachri (PI 614521), groups, where resistance had been previously described. Other melon accessions that were susceptible to both main virus isolates were some Indian accessions of momordica and conomon that otherwise are multi-resistant to other viruses: Shiro Uri Okayama, which is resistant to cucumber mosaic virus (CMV) [23], accession PI 124112, which is resistant to cucurbit aphid-born yellows virus and tomato leaf curl New Delhi virus [13] and momordica PI 180280, which is resistant to papaya ringspot virus and other potyviruses [17,24,25]. Rajamony et al., found mild symptoms when they inoculated Kachri melons [16]. In our study, PI 164493 was found susceptible to CGMMV but strong symptoms took one additional week to appear when inoculated with the Asian isolate than with the European one (Table S1). Although plants were observed for symptom expression beyond $21 \mathrm{dpi}$, no further changes were found, agreeing with the evolution of CGMMV in cucumber [26].

The expression of symptoms following inoculation with CGMMV was variable in other melon accessions. The makuwa melon PI 420176 already expressed severe symptoms with the Asian isolate after $14 \mathrm{dpi}$, and intermediate symptoms with the European isolate after $21 \mathrm{dpi}$, similarly to the Rochet type. The chinensis Korean accession PI 161375 "Sonwang Charmi" and the flexuosus melon BGV004853 showed the opposite behavior, expressing strong symptoms with the European isolate after $21 \mathrm{dpi}$, and intermediate symptoms with the Asian isolate after $14 \mathrm{dpi}$. PI 420176 and PI 161375 are resistant to CMV and multiresistant, respectively $[13,27]$. The resistance to CMV, however, is dependent on the strain of the virus, which constitutes another example of the importance of considering different viral strains in the characterization of resistance in plants [28]. Accession PI 161375 is also resistant to a different cucurbit-infecting tobamovirus, Kyuri green mottle mosaic virus [29], and whether the isolate-specific intermediate resistance that we observed suggests a common origin of resistance directed towards Asian cucurbit infecting tobamoviruses could be further investigated.

The resistance of the other 16 melon accessions depended on the isolate of CGMMV. They were very susceptible to the Asian isolate but showed resistance to the European isolate. These included mostly accessions belonging to the cantalupensis and reticulatus (Europe) and ameri, chandalak and casaba (Asia and North-Africa) melon types (Table S2).

The clear identification of CGMMV isolates and strains is fundamental to determine resistance to CGMMV, as has already been reported in cucumber [26]. Here, we confirmed that $C$. anguria is resistant to isolates of both the European and Asian strains [26]. Others have found this plant species to be resistant to the European [30], and susceptible to the Asian strains of CGMMV [16]. C. myriocarpus produced intermediate symptoms with the European isolate and remained symptomless following the inoculation with the Asian strain, whereas C. ficifolius was symptomless with the isolates of both strains (Table S1). 
Earlier studies found C. myriocarpus and C. ficifolius symptomless to the Asian isolate of CGMMV [16].

The Asian isolate of CGMMV proved to be very aggressive on many of the varieties tested. Interestingly, we found resistance to the European isolate in a significant number of cantalupensis, reticulatus, ameri, chandalak, cand Kachri accessions, which originate from European, Central Asia, Asia Minor and North African countries. Asian ameri and chandalak types seem to be at the origin of the cantalupensis varieties which are molecularly different from far eastern melon varieties [31-33], and which would fit with a common response to the virus. These accessions are interesting candidates for melon breeding for resistance to the European CGMMV strain. The highest degree of resistance to both CGMMV isolates was found for Freeman's Cucumber; this conomon melon type from Japan is also resistant to CMV [34]. The genetics of resistance to CGMMV in melon is not known. CMV and CGMMV are both linear positive-sense RNA viruses but they are unrelated. CMV is a member of the family Bromoviridae, genus Cucumovirus. This virus has a very wide host range and is predominantly transmitted from plant to plant by aphids in a stylet-borne fashion. Its genome is tripartite surrounded by isometric particles. On the other hand, CGMMV is member species of a different plant virus family and, although, at least 15 weed species from nine different plant families have been identified as potential natural hosts, its host range is restricted to plant species in the family Cucurbitaceae. It is not transmitted by insects, but mainly through contact and infected soil or seeds [5].

Here, we report on melon accessions that are described for the first time as resistant to CGMMV. Freeman's Cucumber (Conomon, Japan) is shown here, for the first time, to be resistant to CGMMV, and this entry is of enormous interest as it crosses perfectly with melons. With respect to wild species, we confirm the resistance of $C$. anguria and C. ficifolius to isolates of both CGMMV strains. These species do not cross with melons so they cannot be used as sources of resistance in breeding programs, but they are useful as rootstocks. In fact, a hybrid rootstock between $C$. anguria and $C$. ficifolius for melon grafting has already been described [22,35]. This rootstock has resistance to nematodes and soil fungi, but the fact that it also has resistance to CGMMV, a virus that is also transmitted through the soil, makes it much more interesting.

\section{Materials and Methods}

\subsection{Plant Material}

Forty-seven accessions were selected from a previously established melon core collection to represent some of the most important $C$. melo groups, including accessions of the momordica, Kachri, and makuwa, the melon groups in which CGMMV has been previously reported, and additional inodorus-ibericus, cantalupensis-reticulatus, casaba, Asian americhandalack, flexuosus, Dudaim, conomon, chinensis and wild agrestis types not screened previously $[17,31,32,36]$. Accessions of this collection come from different germplasm and breeder collections, and were maintained and multiplied under insect-proof conditions by the Cucurbits breeding group at COMAV-UPV. The type and origin of these accessions is shown in Table 1. Four wild species C. anguria, C. ficifolius, C. myriocarpus and C. metuliferus coming from the COMAVs germplasm collection were also included.

Table 1. Melon and wild Cucumis accessions screened for resistance to CGMMV.

\begin{tabular}{ccc}
\hline Accession ID & Accession Name & Country of Origin \\
\hline & C. melo subsp. Melo \\
\hline BGV016451 & Inodorus-ibericus Spanish landraces \\
\hline BGV015753 & Amarillo Groc & Spain \\
\hline BGV004871 & Blanco & Spain \\
\hline
\end{tabular}


Table 1. Cont.

\begin{tabular}{|c|c|c|}
\hline Accession ID & Accession Name & Country of Origin \\
\hline BGV013188 & Pipa de oro & Spain \\
\hline BGV003686 & Piñoncillo & Spain \\
\hline BGV003692 & Blanco Redondo & Spain \\
\hline BGV003718 & Mochuelo & Spain \\
\hline BGV004884 & Melón Rochet & Spain \\
\hline \multicolumn{3}{|c|}{ Ameri/adana/chandalak/casaba and other landraces from Europe and Asia } \\
\hline PI 125951 & 3584 & Afghanistan \\
\hline BGV001367 & Nanatri & Georgia \\
\hline PI 314427 & Koljoznitza & Georgia \\
\hline CUM 259 & Apelsinaja & Russia \\
\hline PI 276660 & VIR610-chandalak & Afghanistan \\
\hline BGV001364 & Asli & Tunisia \\
\hline BGV001365 & Tokash & Tajikistan \\
\hline PI 169331 & Altimbas & Turkey \\
\hline PI 506459 & Salgirskaja & Ukraine \\
\hline BGV001362 & Kizil-uruk & Uzbekistan \\
\hline PI 169305 & Kirkagac & Turkey \\
\hline PI 476342 & Imljskaha & Kazakhstan \\
\hline Am-BirUkr & Birjucekutskaja & Ukraine \\
\hline In-HamiChi & Hami Melon & China \\
\hline Am-OuzUzb2 & Ouzbeque & Uzbekistan \\
\hline Am-SouiMor & Souilah & Morocco \\
\hline \multicolumn{3}{|c|}{$\begin{array}{l}\text { Cantalupensis and reticulatus commercial cultivars and landraces } \\
\text { from Europe, Asia, and America }\end{array}$} \\
\hline Can-VedFran & Vedrantais & France \\
\hline Can-NYIsr & Noy Israel & Israel \\
\hline Can-NOFran & Nantais Oblong & France \\
\hline Ames 26811 & PMR-45 & USA \\
\hline La-OgenBul & Dvash Ha Ogen & Bulgaria \\
\hline \multicolumn{3}{|c|}{ Flexuosus and Dudaim accessions } \\
\hline BGV004853 & Alficoz & Spain \\
\hline PI 273438 & $\begin{array}{l}\text { Queen Anne's Pocket Melon } \\
\text { C. melo subsp. agrestis }\end{array}$ & Georgia \\
\hline \multicolumn{3}{|c|}{ Momordica accessions and other landraces from India } \\
\hline PI 124112 & 2564 & India \\
\hline PI 180280 & Kahkri & India \\
\hline PI 381781 & Sm1 & India \\
\hline PI 381789 & Sm9 & India \\
\hline PI 271332 & Khira & India \\
\hline
\end{tabular}


Table 1. Cont.

\begin{tabular}{|c|c|c|}
\hline Accession ID & Accession Name & Country of Origin \\
\hline \multicolumn{3}{|c|}{ Conomon, chinensis and makuwa accessions from Far East } \\
\hline PI 420176 & Ginsen makuwa & Japan \\
\hline Con-FreeCJa & Freeman's Cucumber & Japan \\
\hline PI 161375 & Songwhan Charmi & Korea \\
\hline Con-ShiroJa & Shiro Uri Okayama & Japan \\
\hline \multicolumn{3}{|c|}{ Kachri and wild agrestis from Asia and Africa } \\
\hline Am-SarakIran & Sarakhs & Iran \\
\hline PI 614521 & KSM 531 Kachri & India \\
\hline PI 164493 & Kakru & India \\
\hline PI 185111 & 15591 & Ghana \\
\hline PI 164797 & 9227 & India \\
\hline PI 532839 & Chibbar & India \\
\hline PI 536476 & KLM 1733 & Maldives \\
\hline \multicolumn{3}{|c|}{ Wild Cucumis spp. } \\
\hline BGV11135 & C. metuliferus & \\
\hline BGV012786 & C. ficifolius & \\
\hline BGV012795 & C. anguria & \\
\hline BGV008535 & C. myriocarpus & \\
\hline
\end{tabular}

\subsection{Virus Sources for Mechanical Inoculation}

In order to investigate differences in resistance, we mechanically inoculated plants with each one of two isolates that represent the two different strains of CGMMV: the strain of European origin (CGMMV-SP) (GenBank GQ411361) and that of Asian origin (CG-SPCu16), as described by [10]. Before its use in screening the Cucumis accessions, the isolates were propagated after mechanical inoculation in cucumber (cv. Cumlaude) in a plant growth chamber. Infected plants were grown in an insect-proof greenhouse where temperature was partially controlled $\left(25-30^{\circ} \mathrm{C}\right)$. Approximately 3 weeks after inoculation, the leaves of plants that showed typical symptoms of virus infection were used as the virus source [26].

\subsection{Mechanical Inoculation}

For each virus isolate, $0.5 \mathrm{~g}$ of leaf tissue was taken at 5 weeks after sowing and from the second leaf down from the plant apex which displayed CGMMV symptoms. The tissue was homogenized in $1.5 \mathrm{~mL}$ of $50 \mathrm{mM}$ sodium phosphate buffer ( $\mathrm{pH} 7.0$ ) and inoculated mechanically by rubbing $150 \mu \mathrm{L}$ of the extract onto leaves dusted with carborundum powder. At least ten plants of each accession were inoculated with each virus isolate, and two plants with sodium phosphate buffer as controls on 7th of October 2019. All inoculated plants were maintained in an insect-proof greenhouse under controlled conditions.

\subsection{Evaluation of Symptoms and Quantification of the Virus}

Inoculated plants were evaluated for the expression of CGMMV symptoms at 14 and 21 days post inoculation (dpi) using the following scale: 0 (symptomless), 1 (mild symptoms, as initial mottle mosaic on leaves), 2 (intermediate symptoms, as evident leaf mottle mosaic on leaves) and 3 (severe symptoms as mottle mosaic, interveinal chlorosis and blistering on leaves) (Figure 1). The presence of the virus was analyzed in two pools of five plants each. At 14 and $21 \mathrm{dpi}$, samples of $0.2 \mathrm{~g}$ tissue were removed from the second leaf (not inoculated, and possibly representing systemic infection) from the apex. The 
pooled samples were ground to a fine powder in liquid nitrogen in a pestle and mortar and placed in a sterile microcentrifuge tube. Total RNA was extracted with Trizol reagent (Invitrogen). The resulting pellet was resuspended in $50 \mu \mathrm{L}$ DEPC-treated water and stored at $-80^{\circ} \mathrm{C}$. RNA was quantified with an ND-2000c spectrophotometer (NanoDrop Technologies, Thermo Fisher Scientific S.L, Madrid, Spain) and diluted to a final concentration of $50 \mathrm{ng} / \mu \mathrm{L}$. Real-time RT-PCR reactions were set up in 96-well reaction plates: one microliter aliquots were used as templates in the RT-PCR reactions of $20 \mu \mathrm{L}$, containing $10 \mu \mathrm{L}$ Master Mix (qMAXSen ${ }^{\mathrm{TM}}$ One-Step Green RT-qPCR Kit, Canvax Biotech, Cordoba, Spain), $1 \mu \mathrm{L}$ forward primer, $1 \mu \mathrm{L}$ reverse primer, $1 \mu \mathrm{L}$ total RNA and $7 \mu \mathrm{L}$ DEPC-water. The primers for CGMMV were 5'-GCATAGTGCTTTCCCGTTCAC-3' (sense) at positions 6285$6305 \mathrm{nt}$ and TGCAGAATTACTGCCCATAGAAAC-3' (antisense) at positions 6362-6385 nt of the genome sequence, as described [25]. Primers and probe for the internal control were designed based on the peptidyl-prolyl cis-trans isomerase, cyclophilin (CYP 7) gene MELO3C025848.2 [37]: primers CYP-7F (5'-TACTGGACCAGGCCTCCTAT-3'), CYP-7R (5'TAGGTGTTCCGTTCTGCCTT-3 $\left.{ }^{\prime}\right)$ and Taqman probe CYP-7TM (5'-TGGCAAACGCTGGTC CAGACACCA- $\left.3^{\prime}\right)$. Cycling conditions consisted of incubation at $95^{\circ} \mathrm{C}$ for $5 \mathrm{~min}, 45 \mathrm{cycles}$ of $95{ }^{\circ} \mathrm{C}$ for $5 \mathrm{~s}$ and $60^{\circ} \mathrm{C}$ for $30 \mathrm{~s}$. Relative CGMMV levels were calculated using the $2^{-\Delta \mathrm{Ct}}$ expression, a variation of the Livak method [38,39], where ratio (reference/target) $=2^{-\Delta \mathrm{Ct}}$ $=2^{-(\mathrm{Ct} \text { (viral target })-\mathrm{Ct}(\text { reference gen }))}$. Three technical replications were performed per sample and the tests were run on an ABI Prism 7000 DNA sequence detection system (Thermo Fisher Scientific S.L, Madrid, Spain) as followed: $10 \mathrm{~min}$ at $50^{\circ} \mathrm{C}, 1 \mathrm{~min}$ at $95^{\circ} \mathrm{C}, 40 \mathrm{cycles}$ of $15 \mathrm{~s}$ at $95^{\circ} \mathrm{C}$ and $1 \mathrm{~min}$ at $60^{\circ} \mathrm{C}$.

\subsection{Data Analysis}

Resistance was evaluated as the response of the host plant to virus infection, estimated from symptom severity and the viral titers in all inoculated plants. The interaction effects from inoculated isolates of virus, and dpi on viral loads, were investigated using the Kruskal-Wallis test. All effects were tested at the 5\% significance level. Analyses were performed using Statistics 9.1 statistical software.

Supplementary Materials: The following are available online at https:/ /www.mdpi.com/article/10 .3390 / plants10061077/s1, Table S1. Symptom expression in C. melo and four wild Cucumis species inoculated with the European and Asian isolates of CGMMV; Table S2. Relative accumulation (RA) and standard error (SE) of CGMMV in C. melo and in four wild Cucumis species inoculated with the European and Asian isolates.

Author Contributions: Conceptualization, D.J. and B.P.; methodology, L.R., C.L. and D.J.; formal analysis, L.R. and D.J.; writing-original draft preparation, L.R., C.L., B.P. and D.J.; writing-review and editing, L.R., C.L., B.P. and D.J. All authors have read and agreed to the published version of the manuscript.

Funding: This research was funded by RTA2017-00061-C03 from the Ministry of Economy and Competitiveness (MINECO), and the State Research Agency from Spain, by AGL2017-85563-C21-R from the Spanish Ministerio de Ciencia, Innovación y Universidades, cofunded with FEDER funds, and by the PROMETEO project 2017/078 (to promote excellence groups) by the Conselleria d'Educació, Investigació, Cultura i Esports (Generalitat Valenciana).

Institutional Review Board Statement: Not applicable.

Informed Consent Statement: Not applicable.

Data Availability Statement: All data generated or analyzed are contained within the present article.

Acknowledgments: We also want to thank Antonia Belmonte and Eva María Martínez Pérez for technical assistance, and to the Genebanks COMAV, USDA-NPGS, and IPK for providing seeds of some of the accessions used in this work.

Conflicts of Interest: The authors declare no conflict of interest. 


\section{References}

1. Lovisolo, O. Virus and viroid diseases of cucurbits. Acta Hortic 1980, 88, 33-82. [CrossRef]

2. Adams, M.J.; Antoniw, J.M.; Kreuze, J. Virgaviridae: A new family of rod-shaped plant viruses. Arch. Virol. 2009, 154, 1967-1972. [CrossRef]

3. Mandal, S.; Mandal, B.; Varma, A. Properties, diagnosis and management of Cucumber green mottle mosaic virus. Plant Viruses 2008, 2, 25-34.

4. van Koot, Y.; van Dorst, H.J.M. Virusziekten van komkommer in Nederland (with a summary: Virus diseases of cucumber in the Netherlands). Tijdschr. Plantenziekten 1959, 65, 257-271.

5. Dombrovsky, A.; Tran-Nguyen, L.T.T.; Jones, R.A.C. Cucumber green mottle mosaic virus: Rapidly increasing global distribution, etiology, epidemiology, and management. Ann. Rev. Phytopathol. 2017, 55, 231-256. [CrossRef] [PubMed]

6. Liu, H.W.; Luo, L.X.; Li, J.Q.; Liu, P.F.; Chen, X.Y.; Hao, J.J. Pollen and seed transmission of Cucumber green mottle mosaic virus in cucumber. Plant Pathol. 2014, 63, 72-77. [CrossRef]

7. Ainsworth, G.C. Mosaic disease of cucumber. Ann. Appl. Biol. 1935, 22, 55-67. [CrossRef]

8. Reingold, V.; Lachman, O.; Blaosov, E.; Dombrovsky, A. Seed disinfection treatments do not sufficiently eliminate the infectivity of Cucumber green mottle mosaic virus (CGMMV) on cucurbit seeds. Plant Pathol. 2015, 64, 245-255. [CrossRef]

9. Reingold, V.; Lachman, O.; Belausov, E.; Koren, A.; Mor, N.; Dombrovsky, A. Epidemiological study of Cucumber green mottle mosaic virus in greenhouses enables reduction of disease damage in cucurbit production. Ann. Appl. Biol. 2016, 168, 29-40. [CrossRef]

10. Crespo, O.; Janssen, D.; García, C.; Ruiz, L. Biological and molecular diversity of Cucumber green mottle mosaic virus in Spain. Plant Dis. 2017, 101, 977-984. [CrossRef] [PubMed]

11. Marco, C.F.; Aguilar, J.M.; Abad, J.; Gómez-Guillamón, M.L.; Aranda, M.A. Melon resistance to Cucurbit yellow stunting disorder virus in characterized by reduced virus accumulation. Phytopathology 2003, 93, 844-852. [CrossRef]

12. Díaz-Pendón, J.A.; Fernández-Muñoz, R.; Gómez-Guillamón, M.L.; Moriones, E. Inheritance of resistance to Watermelon mosaic virus in Cucumis melo that impairs virus accumulation, symptom expression, and aphid transmission. Phytopathology 2005, 95, 840-846. [CrossRef]

13. Martín-Hernández, A.M.; Picó, B. Natural resistances to viruses in cucurbits. Agronomy 2021, 11, 23. [CrossRef]

14. FAOStat. 2020. Available online: www.fao.org/faostat (accessed on 20 March 2021).

15. Ali, E.M.; Tabei, Y.; Kobayashi, K.; Yamaoka, N.; Nishiguchi, M. Molecular analysis of transgenic melon plants showing virus resistance conferred by direct repeat of movement gene of Cucumber green mottle mosaic virus. Plant Cell Rep. 2012, 31, 1371-1377. [CrossRef]

16. Rajamony, L.; More, T.A.; Seshadri, V.S.; Varma, A. Reaction of muskmelon collections to Cucumber green mottle mosaic virus. J. Phytopathol. 1990, 129, 237-244. [CrossRef]

17. Pitrat, M. Disease resistance in melon and its modification by molecular breeding techniques. In Functional Genomics and Biotechnology in Solanaceae and Cucurbitaceae Crops; Ezura, H., Ariizumi, T., Garcia-Mas, J., Rose, J., Eds.; Springer: Berlin/Heidelberg, Germany, 2016; pp. 175-197.

18. Rajamony, L.; More, T.A.; Seshadri, V.S. Inheritance of resistance to Cucumber green mottle mosaic virus in muskmelon (Cucumis melo L.). Euphytica 1990, 47, 93-97.

19. Pan, R.S.; More, T.A. Screening of melon (Cucumis melo L.) germplasm for multiple disease resistance. Euphytica 1996, 88, 125-128. [CrossRef]

20. Sugiyama, M.; Ohara, T.; Sakata, Y. A new source of resistance to Cucumber green mottle mosaic virus in melon. J. Jpn. Soc. Hortic. Sci. 2006, 75, 469-475. [CrossRef]

21. Sugiyama, M.; Ohara, T.; Sakata, Y. Inheritance of resistance to Cucumber green mottle mosaic virus in Cucumis melo L. 'Chang Bougi'. J. Jpn. Soc. Hortic. Sci. 2007, 76, 316-318. [CrossRef]

22. Flores-León, A.; García-Martínez, S.; González, V.; Garcés-Claver, A.; Martí, R.; Julián, C.; Sifres, A.; Pérez-de-Castro, A.; Díez, M.J.; López, C.; et al. Grafting snake melon [Cucumis melo L. subsp. melo Var. flexuosus (L.) Naudin] in organic farming: Effects on agronomic performance; resistance to pathogens; sugar, acid, and VOC profiles; and consumer acceptance. Front. Plant Sci. 2021, 12, 613845. [CrossRef] [PubMed]

23. Pascual, L.; Yan, J.; Pujol, M.; Monforte, A.J.; Picó, B.; Martín-Hernández, A.M. CmVPS41 Is a general gatekeeper for resistance to Cucumber mosaic virus phloem entry in melon. Front. Plant Sci. 2019, 10, 1219. [CrossRef]

24. Brotman, Y.; Normantovich, M.; Goldenberg, Z.; Zvirin, Z.; Kovalski, I.; Stovbun, N.; Doniger, T.; Bolger, A.M.; Troadec, C.; Bendahmane, A.; et al. Dual resistance of melon to Fusarium oxysporum Races 0 and 2 and to Papaya ring-spot virus is controlled by a pair of head-to-head-oriented NB-LRR genes of unusual architecture. Mol. Plant 2013, 6, 235-238. [CrossRef]

25. Pitrat, M.; Lecoq, H. Two alleles for Watermelon Mosaic Virus 1 resistance in melon. Cucurbit Genet. Coop. Rep. $1983,6,52-53$.

26. Crespo, O.; Janssen, D.; Robles, C.; Ruiz, L. Resistance to Cucumber green mottle mosaic virus in Cucumis sativus. Euphytica 2018, 214, 201. [CrossRef]

27. Giner, A.; Pascual, L.; Bourgeois, M.; Gyetvai, G.; Rios, P.; Picó, B.; Troadec, C.; Bendahmane, A.; Garcia-Mas, J.; Martín-Hernández, A.M. A mutation in the melon Vacuolar Protein Sorting 41prevents systemic infection of Cucumber mosaic virus. Sci. Rep. 2017, 7, 10471. [CrossRef] 
28. Díaz, J.A.; Mallor, C.; Soria, C.; Camero, R.; Garzo, E.; Fereres, A.; Alvarez, J.M.; Gómez-Guillamón, M.L.; Luis-Arteaga, M.; Moriones, E. Potential sources of resistance for melon to nonpersistently aphidborne viruses. Plant Dis. 2003, 87, 960-964. [CrossRef] [PubMed]

29. Daryono, B.S.; Somowiyarjo, S.; Natsuaki, K.T. Biological and molecular characterization of melon-Infecting Kyuri green mottle mosaic virus in Indonesia. J. Phytopathol. 2005, 153, 588-595. [CrossRef]

30. Den Nijs, A.P.M. Inheritance of resistance to Cucumber green mottle mosaic virus (Cgm) in Cucumis anguria L. Cucurbit Gen. Coop. Rep. 1982, 5, 57-58.

31. Esteras, C.; Formisano, G.; Roig, C.; Díaz, A.; Blanca, J.; Garcia-Mas, J.; Gómez-Guillamón, M.L.; López-Sesé, A.I.; Lázaro, A.; Monforte, A.J.; et al. SNP genotyping in melons: Genetic variation, population structure, and linkage disequilibrium. Theor. Appl. Genet. 2013, 126, 1285-1303. [CrossRef] [PubMed]

32. Leida, C.; Moser, C.; Esteras, C.; Sulpice, R.; Lunn, J.E.; de Langen, F.; Monforte, A.J.; Picó, B. Variability of candidate genes, genetic structure and association with sugar accumulation and climacteric behavior in a broad germplasm collection of melon (Cucumis melo L.). BMC Genet. 2015, 16, 28. [CrossRef] [PubMed]

33. Gonzalo, M.J.; Díaz, A.; Dhillon, N.P.S.; Reddy, U.K.; Picó, B.; Monforte, A.J. Re-evaluation of the role of Indian germplasm as center of melon diversification based on genotyping-by-sequencing analysis. BMC Genom. 2019, 20, 448. [CrossRef] [PubMed]

34. Karchi, Z.; Cohen, S.; Govers, A. Inheritance of resistance to Cucumber mosaic virus in melons. Phytopathology 1975, 65, 479-481. [CrossRef]

35. Cáceres-Burbano, A.; Perpiña Martin, G.; Ferriol Molina, M.; Picó Sirvent, M.B.; Gisbert Domenech, M.C. New Cucumis rootstocks for melon: 'UPV-FA' and 'UPV-FMy'. HortScience 2017, 52, 792-797. [CrossRef]

36. Esteras, C.; Lunn, J.; Sulpice, R.; Blanca, J.; Garcia-Mas, J.; Pitrat, M.; Nuez, F.; Picó, B. Phenotyping a highly diverse core melon collection to be screened using Ecotilling. In Proceedings of the 8th Plant Genomics European Meeting, Lisbon, Portugal, 7-10 October 2009.

37. Sáez, C.; Martínez, C.; Ferriol, M.; Manzano, S.; Velasco, L.; Jamilena, M.; López, C.; Picó, B. Resistance to Tomato leaf curl New Delhi virus in Cucurbita spp. Ann. Appl. Biol. 2016, 169, 91-105. [CrossRef]

38. Bio-Rad Laboratories Inc. Real-Time PCR Applications Guide; Bio-Rad Laboratories Inc.: Hercules, CA, USA, 2006 ; p. 100.

39. Livak, K.J.; Schmittgen, T.D. Analysis of relative gene expression data using real-time quantitative PCR and the 2 (-Delta Delta c (t)) method. Methods 2001, 25, 402-408. [CrossRef] 